\title{
RESPONSE TO HYPERCAPNIA UNDER KETAMINE ANAESTHESIA
}

\author{
Magdi G. Solman, G. Fred Brindle, and Gustavo Kuster
}

\section{INTRODUCTION}

Ketamine, a phencyclidine derivative, was introduced into clinical anaesthesia following extensive investigation. Depression of respiration was reported to be minimal provided excessive doses were not used.

Since ketamine is used mainly with spontaneous breathing the incidence of hypercapnia might be expected to be high. To date, the only study assessing the response to hypercapnia under ketamine anaesthesia was published by Kelly et $a l .{ }^{1}$ They demonstrated increase in respiratory rate and minute ventilation in response to the inhalation of 5 per cent carbon dioxide. However, they limited their observations of the change in the $\mathrm{CO}_{2}$ response curve to a single measurement, and no other effects of hypercapnia were reported.

This study was designed to investigate the effect in dogs of ketamine anaesthesia on the carbon dioxide response curve and the catecholamine response to hypercapnia.

\section{METHODS}

Twenty-four mongrel dogs with a mean body weight of $21 \mathrm{~kg}$ were studied. Depending on the type of premedication, the experiments were divided into three groups:

Group I 14 dogs received atropine $0.4 \mathrm{mg}$ I.M.

Grour II 5 dogs received atropine $0.4 \mathrm{mg}+$ pentobarbitone $5 \mathrm{mg} / \mathrm{kg} \mathrm{I.M.}$

Group III 5 dogs received atropine $0.4 \mathrm{mg}+$ morphine $0.1 \mathrm{mg} / \mathrm{kg}$ I.M.

Anaesthesia was induced one hour after premedication with intramuscular ketamine in a dose of $40 \mathrm{mg} / \mathrm{kg}$. Maintenance was provided with a continuous intravenous infusion of 0.5 per cent ketamine in 5 per cent dextrose through a forelimb vein. The rate of infusion was adjusted to prevent reaction to tail clamping.

The trachea was intubated, a canula was inserted into a carotid artery and a catheter was placed into the right atrium through an external jugular vein. Lead II electrocardiogram was monitored continuously.

The tracheal tube was then connected to a closed anaesthetic circuit containing an infra-red carbon dioxide analyser ("Capnograph-Godart"), a Douglas bag with a 3-way stop-cock, a directional valve, and a Wright respirometer (Figure 1). Minute volume was determined by collecting expired air in the Douglas bag and determining its volume using a chain compensated gasometer.

Following completion of the surgical preparation, an inspiratory mixture of 30

From The Department of Anaesthesia, Centre Hospitalier Universitaire, Sherbrooke, Quebec. This study was supported by grant NA-4602 from the Medical Research Council of Canada. 


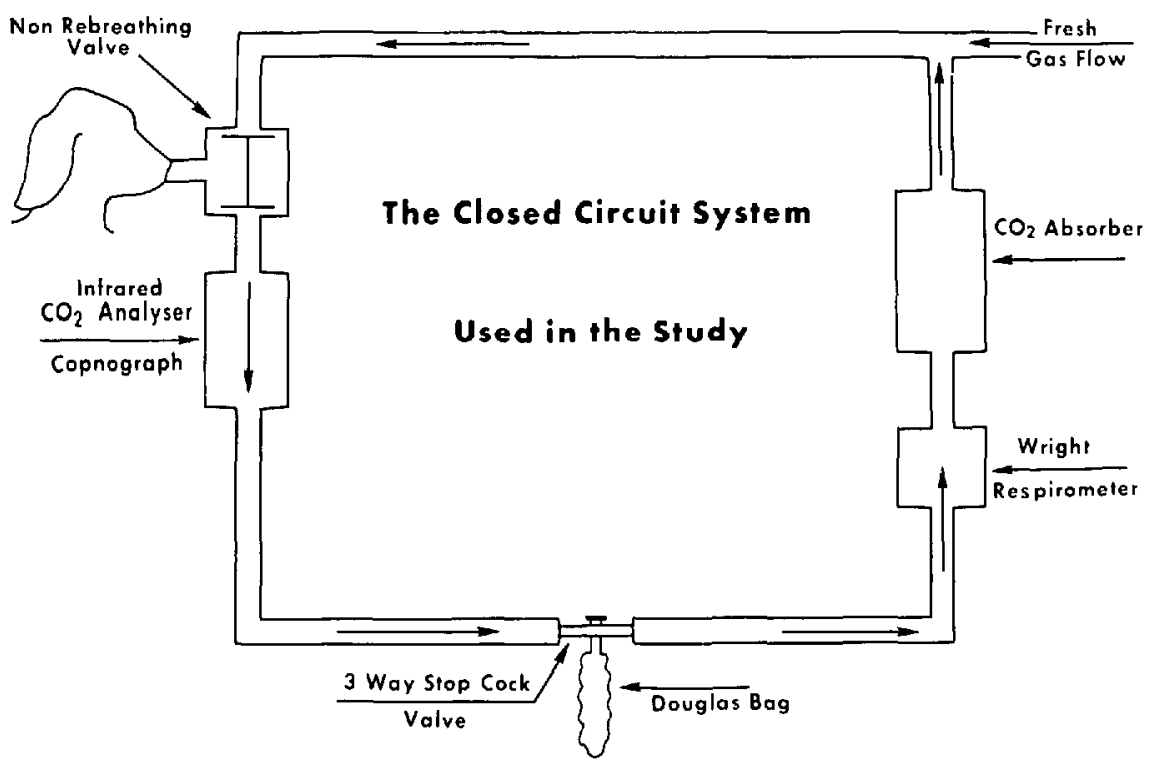

Figure 1

per cent oxygen in nitrogen was given for at least 15 minutes with the carbon dioxide absorber turned on. When vital signs had stabilized, respiratory rate, arterial blood pressure and central venous pressure were measured. Arterial blood samples were drawn for blood gas measurements, determination of acid-base status and measurement of catecholamine levels.

Following these measurements, the carbon dioxide absorber was turned off and 100 per cent oxygen was given at a low flow to allow accumulation of endogenous carbon dioxide.

With the exception of plasma catecholamines all other parameters were measured at intervals of $10 \mathrm{~mm}$ of increment during step-wise increases in the $\mathrm{Pa}_{\mathrm{OO}_{2}}$ from 25 Torr to 90 Torr. $\mathrm{A}$ total of six readings were made for each dog.

Catecholamine plasma levels were measured at the beginning, half way and at the end of carbon dioxide accumulation in group I. Infusion of fluids was controlled to maintain a constant central venous pressure. The carbon dioxide response curve was obtained by linear regression analyses of the minute volume changes in relation to changes in $\mathrm{Pa}_{\mathrm{CO}_{2}}$.

\section{RESUlTS}

The $\mathrm{Pa}_{\mathrm{CO} 2}$ levels of the three groups 15 minutes after the last surgical stimulus are shown in Table $\mathrm{I}$. $\mathrm{Pa}_{\mathrm{CO}}$ is at or below the normal level in all groups. The difference between the three groups is not statistically significant.

\section{TABLE I}

Arterial $\mathrm{P}_{\mathrm{CO}_{2}} \pm \mathrm{SE} 15$ Min after the Last SuRgical Stimulus

\begin{tabular}{ll}
\hline \hline Group I & $28 \pm 0.75^{*}$ \\
Group II & $31 \pm 2.3^{*}$ \\
Group III & $34.8 \pm 2.9^{*}$ \\
\hline
\end{tabular}

*Statistically non significant. 

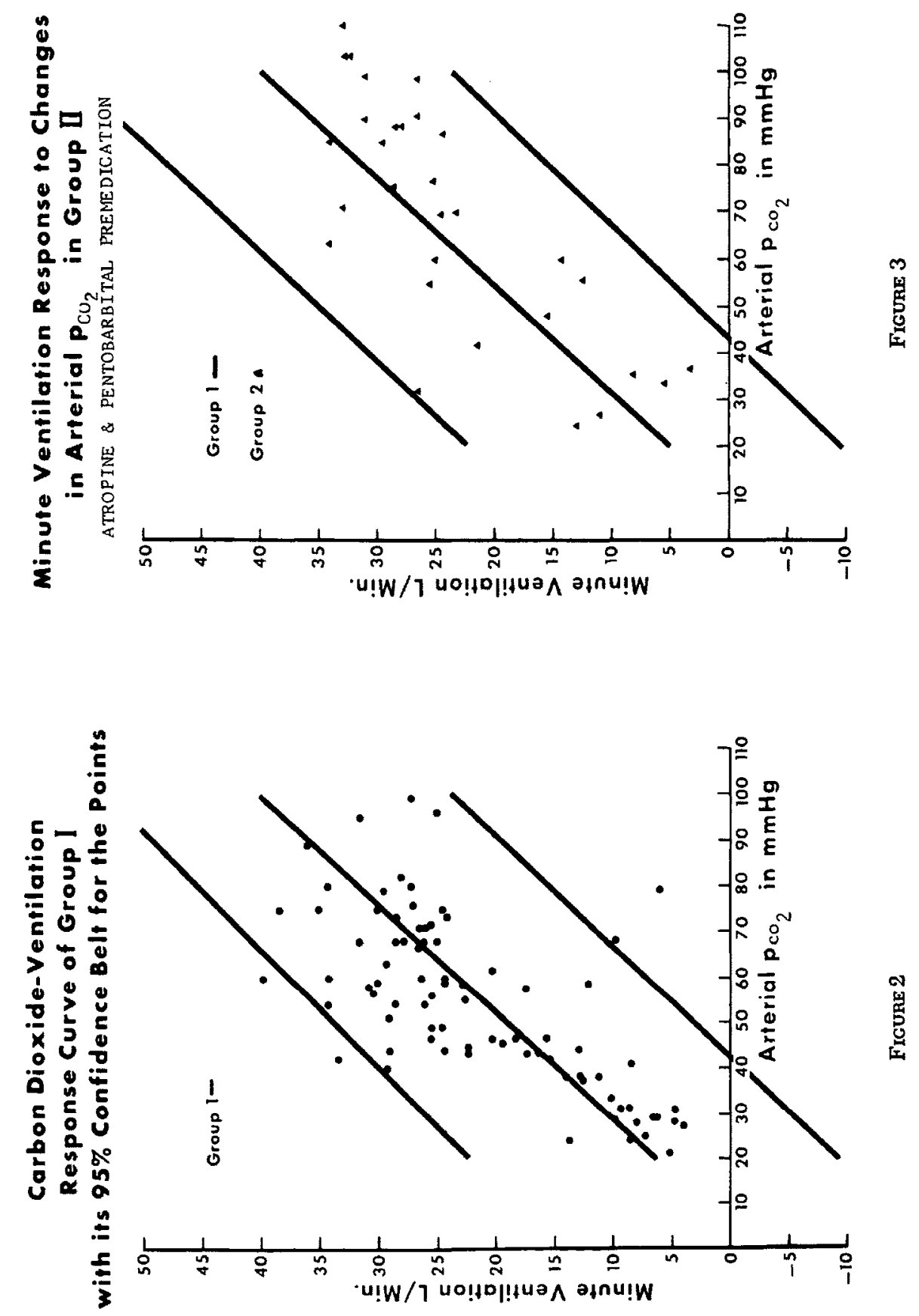


\section{Minute Ventilation Response to Changes in Arterial $\mathrm{P}_{\mathrm{CO}_{2}}$ in Group III} (Arropine \& Morphine Premedications)

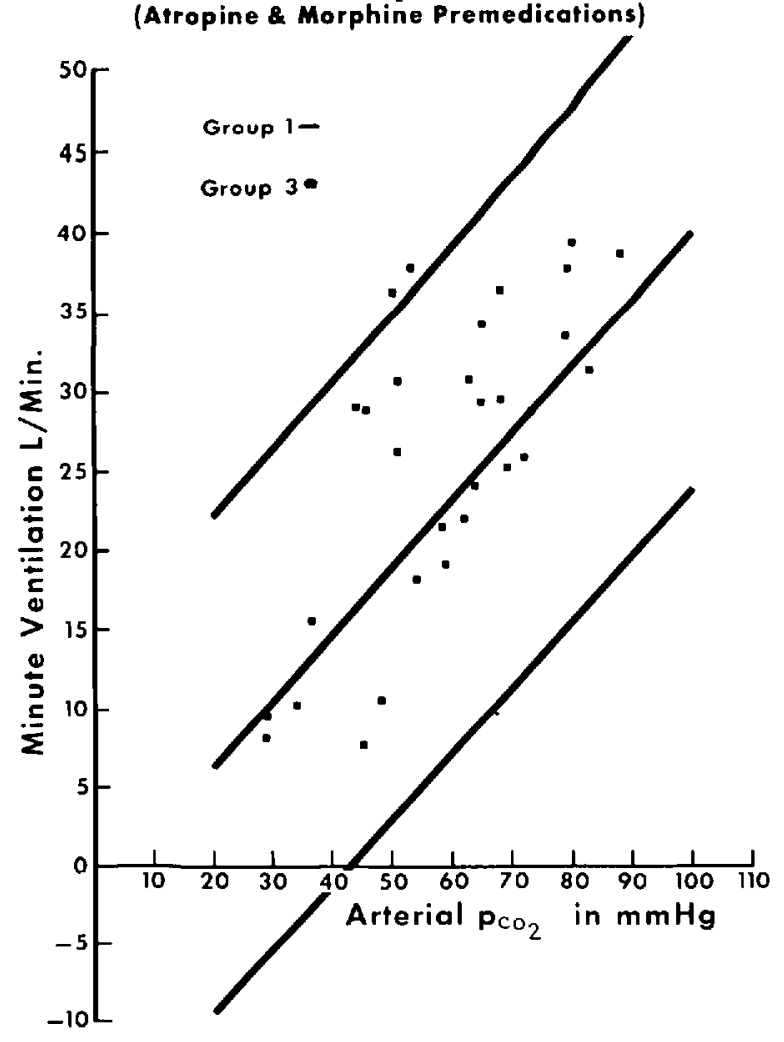

Figure 4

Figure 2 shows the carbon dioxide response curve of group I dogs with the 95 per cent confidence limits for these measurements. The curve has a slope of $0.421 / \mathrm{mmHg}$ of $\mathrm{Pa}_{\mathrm{CO}_{2}}$. Only four determinations out of 81 are outside these limits.

Figure 3 shows the changes of minute ventilation in response to the increases in $\mathrm{Pa}_{\mathrm{CO}_{2}}$ in group II (pentobarbitone premedication). These changes are plotted against the response curve of group $I$ with its 95 per cent confidence belt. All points are located within the 95 per cent confidence limit.

Figure 4 represents the minute ventilation changes in response to the increases in $\mathrm{Pa}_{\mathrm{CO}}$ in group III (morphine premedication). These changes are plotted against the curve of group I with its 95 per cent confidence belt. With the exception of two out of 30 readings all the points are within the confidence limits.

The above mentioned figures show that the ventilatory responses to increases in $\mathrm{Paco}_{2}$ are similar in all groups.

The changes in the heart rate, systolic, diastolic and the mean blood pressures during the period of the study are shown in Figure 5. There is an initial pressor response which gradually decreased by a variable degree from one point to another. 


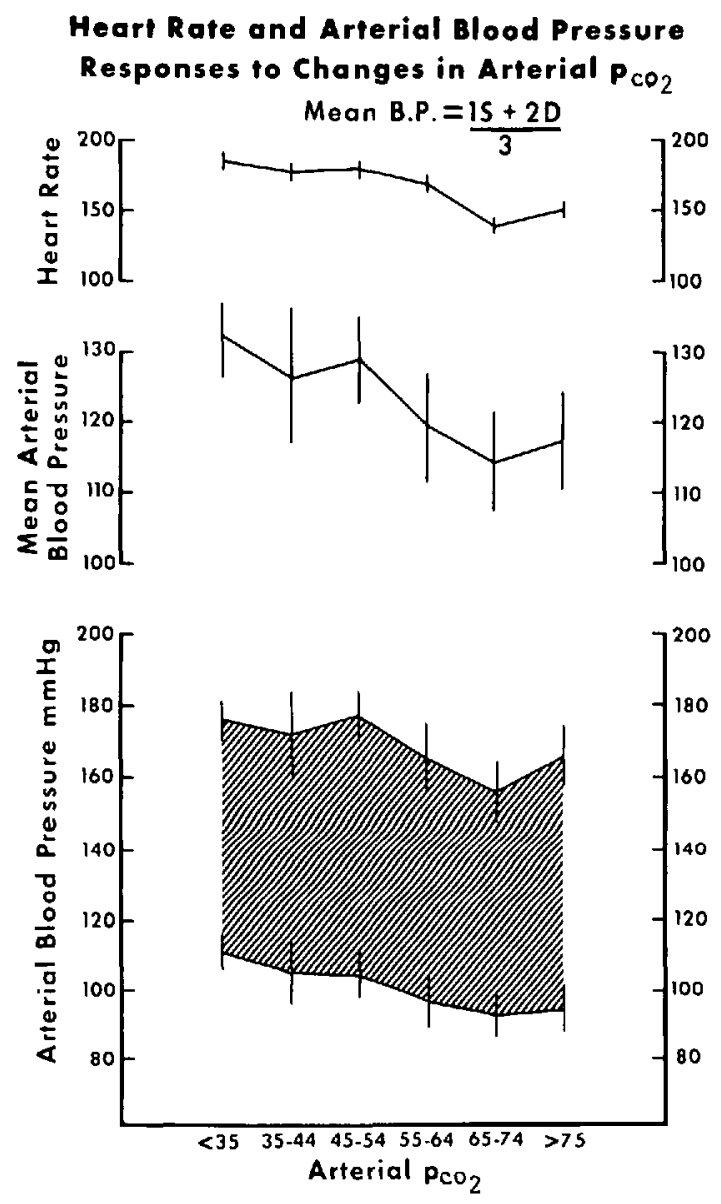

Figure 5

Figure 6 represents the changes in plasma levels of catecholamines during the changes of $\mathrm{Pa}_{\mathrm{CO}_{2}}$ in group I. The initial values are comparable to those of unanaesthetized dogs and there is significant augmentation with the increase in $\mathrm{Pa}_{\mathrm{CO}_{2}}$.

Table II records the $\mathrm{pH}$ and $\mathrm{SE}$ of the mean at various levels of increased $\mathrm{Pa}_{\mathrm{CO}_{2}}$.

Table III shows the doses of ketamine used for induction and maintenance of anaesthesia in the three groups. There was no significant difference.

\section{Discussion}

This study has shown that the respiratory response to hypercapnia was maintained during ketamine anaesthesia. In order to determine whether ketamine produces respiratory stimulation or depression, the carbon dioxide response curve 


\section{Cafecholamines Plasma Levels}

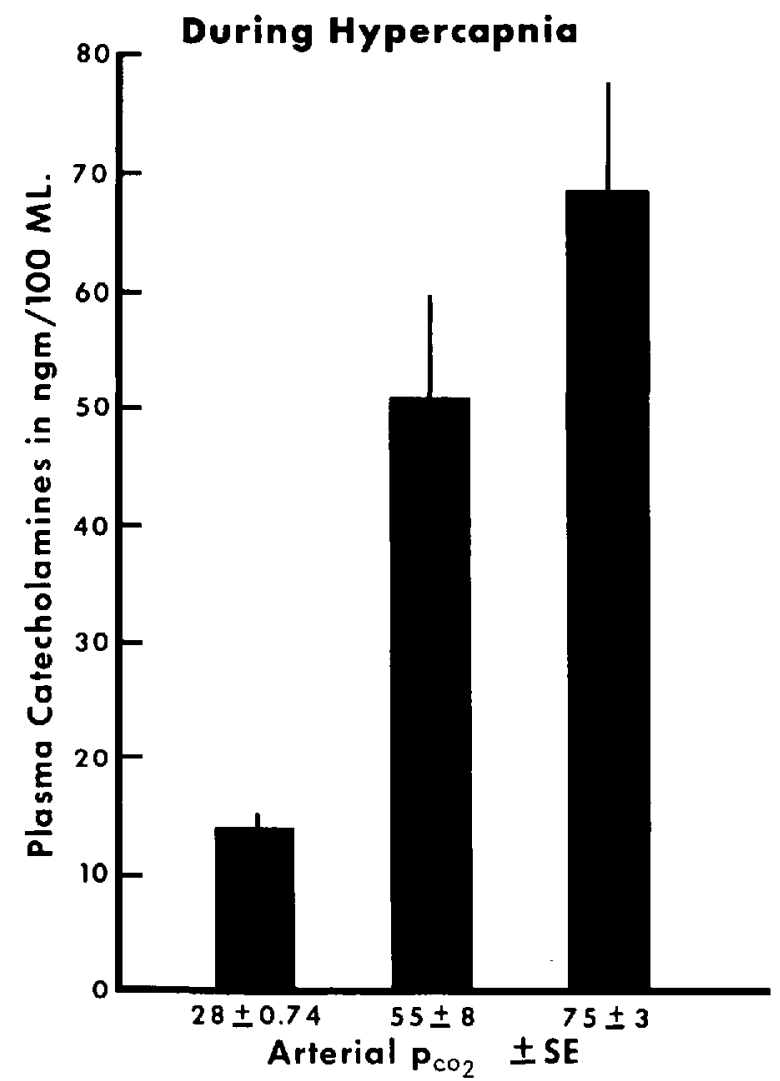

Figure 6

TABLE II

Arterial pH \pm SE at Various Samplings of $\mathrm{PaCO}_{2}$

\begin{tabular}{llll}
\hline \hline $\mathrm{PaCO}_{2}$ & Group I & Group II & Group I I \\
\hline$<35$ & $7.41 \pm 0.001$ & $7.38 \pm 0.04$ & $7.45 \pm 0.03$ \\
$35-44$ & $7.26 \pm 0.02$ & $7.31 \pm 0.07$ & $7.34 \pm 0.01$ \\
$\mathbf{4 5 - 5 4}$ & $7.19 \pm 0.01$ & $7.23 \pm 0.02$ & $7.26 \pm 0.02$ \\
$5.5-64$ & $7.15 \pm 0.01$ & $7.18 \pm 0.04$ & $7.20 \pm 0.01$ \\
$65-74$ & $7.06 \pm 0.01$ & $7.1 \pm 0.01$ & $7.17 \pm 0.02$ \\
$>75$ & $7.0 \pm 0.02$ & $7.0 \pm 0.02$ & $7.08 \pm 0.02$ \\
\hline
\end{tabular}

TABLE III

DOSES OF KETAMINE USED FOR INDUCTION AND Maintenance of Anaesthesia (MG/KG/Hour MEAN $\pm \mathrm{SE}$ )

\begin{tabular}{lccc}
\hline \hline & Group I & Group II & Group III \\
\hline Induction & 40 & 40 & 40 \\
Maintenance & $23.09 \pm 1.8$ & $20.6 \pm 1.73$ & $21.2 \pm 1.65$ \\
\hline
\end{tabular}




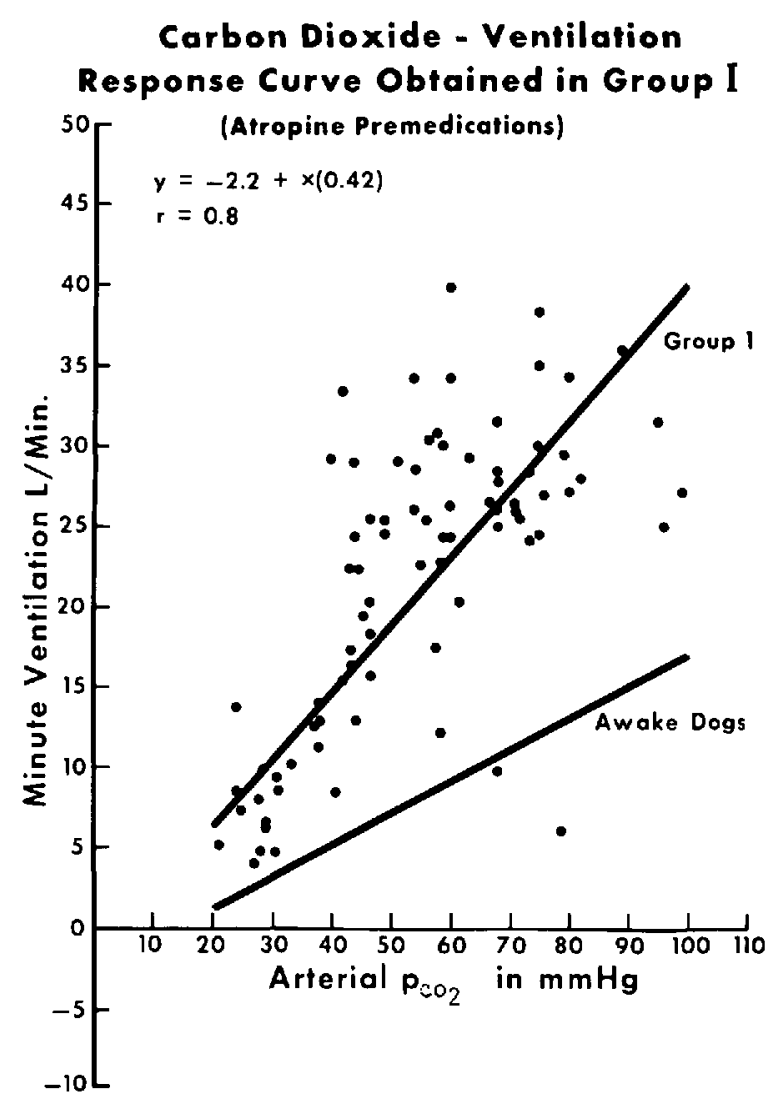

Figure 7

of group I was compared with the curve reported by Eisele et al. ${ }^{7}$ in awake unpremedicated dogs (Figure 7). The group I curve shows a shift to the left with an increase in the slope from 0.22 to $0.42 \mathrm{l} / \mathrm{mm} \mathrm{Hg}$. This change suggests that ketamine induces respiratory stimulation, an effect different from that of narcotics and other intravenous anaesthetic agents. Although the data used for the comparison are not our own, the method by which Eisele et al. obtained their curve permits its use as representative of the normal carbon dioxide ventilation response curve in dogs.

The respiratory stimulating effect of ketamine was not modified by morphine $0.1 \mathrm{mg} / \mathrm{kg}$ nor by pentobarbitone $5 \mathrm{mg} / \mathrm{kg}$ when these drugs were used as preanaesthetic medication.

The mechanisms by which ketamine may produce respiratory stimulation include direct stimulation of the medullary respiratory neurones, or indirect stimulation through peripheral chemoreceptors. Respiratory stimulation secondary to stimulation of higher centres is another possibility. While the peripheral chemoreceptors cannot be excluded, much evidence is in favour of direct stimulation.

Firstly, ketamine has a stimulating effect on the cortical and subcortical regions and also on the brain stem reticular formation. ${ }^{18,19,20}$ It is reasonable to suppose 
that ketamine has an action on the medullary centres similar to that on the higher centres.

Secondly, the cardiovascular pressor response is probably due to stimulation of the medullary cardio-pressor centre ${ }^{9-17}$ and since the cardiovascular and respiratory medullary centres are anatomically intimately related, it is conceivable that the respiratory neurones might be similarly affected.

The stability of the cardiovascular parameters exclude respiratory stimulation secondary to a reflex of cardiovascular origin.

Several reports have suggested the possibility of an increase in plasma catecholamines secondary to ketamine administration. Studies ${ }^{30,32}$ in man and in dogs have demonstrated such an increase and have shown it to be transitory.

The initial levels of catecholamines reported in this study were within normal values and in agreement with these conclusions. Also our increases in plasma catecholamines secondary to increases in $\mathrm{Pa}_{\mathrm{CO}_{2}}$ were similar to those reported by Millar ${ }^{29}$ in dogs under light thiopentone anaesthesia.

\section{SUMMARY}

The respiratory response to hypercapnia in dogs anaesthetized with ketamine was increased. This respiratory stimulation was most probably due to a direct effect of the drug on the medullary respiratory neurones. This effect was not modified by preanaesthetic medication pentobarbitone $5 \mathrm{mg} / \mathrm{kg}$ or morphine 0.1 $\mathrm{mg} / \mathrm{kg}$.

Catecholamine response to hypercapnia was essentially the same as that reported by hypercapnic dogs anaesthetized with thiopentone.

\section{RÉSUMÉ}

La réponse ventilatoire à l'hypercapnie provoquée chez des chiens anesthésiés à la kétamine est augmentée. Cette stimulation respiratoire est, selon toute probabilité attribuable à l'effet direct du médicament, sur les centres respiratoires médullaires. Une prémédication au pentobarbitone $(5 \mathrm{mg} / \mathrm{kg})$ ou à la morphine $(0.1 \mathrm{mg} / \mathrm{kg})$ n’a pas modifié cette réaction.

Le taux de catécholamines lié à l'hypercapnie est essentiellement le même chez les chiens anesthésiés à la kétamine ou au thiopentone.

\section{REFERENCES}

1. Kelly, R.W., Wuson, R.D., Traber, D.L., \& Pruano, L.L. Effects of two new dissociative anaesthetic agents, Ketamine and CL-1848C on the respiratory response to carbon dioxide. Anesthesia \& Analgesia, Current Researches 50: 262 (1971).

2. Eckenhoff, J.E., Helnich, M., \& Hege, M.J.D. A method for studying respiratory functions in awake or anaesthetized patients. Anesthesiology 17:66 (1956).

3. Clark, T.J.H. Simple technique for measuring changes in ventilatory response to $\mathrm{CO}_{2}$. Lancet 2:368 (1966).

4. Jlang, N.S., Staffer, S.S., Pikler, G.M., Wadel, O., \& Sheps, S.G. Laboratory and clinical observations with a two-column plasma catecholamine assay. Proc. Mayo Clin. 48: 47 (1973).

5. Chang, T. \& Grazko, A.J. A gas chromatographic assay for ketamine in human plasma. Anesthesiology 36: 401 ( 1972).

6. Dinl, W.A., Chucot, L., Chang, T., \& Glazko, A.J. Determination of ketamine-blood plasma. Anesthesiology 34: 73 (1971). 
7. Eisele, J.H., Eger II, E.I., \& Muallem, M. Narcotic properties of carbon dioxide in the dog. Anesthesiology 28: 856 (1967).

8. Ito, Y. \& Ichryanagr, K. Post-operative pain relief with ketamine infusion. Anaesthesia 29: $222(1974)$.

9. Dowdy, E.G. \& KAY, K. Studies of the mechanism of cardiovascular responses to CI-581. Anesthesiology 29: 931 (1968).

10. Stanely, V., HUnt, J., Wmlis, K.W., \& Stephen, C.R. Cardiovascular and respiratory function with CI-581. Anesthesia \& Analgesia. Current Researches 47: 760 (1968).

11. Traber, D.L., Wilson, R.D., \& Priano, L.L. Differentiation of the cardiovascular effects of CI-581. Anesthesia \& Analgesia. Current Researches 47: 769 (1968).

12. Thaber, D.L., Wrison, R.D., \& Priano, L.L. Involvement of the sympathetic nervous system in the pressor response to ketamine. Anesthesia \& Analgesia. Current Researches 48: $248(1969)$.

13. Traber, D.L., Wuson, R.D., \& Pruano, L.L. A detailed study of the cardiopulmonary response to ketamine and its blockade by atropine. South Med. J. 63: 1077 (1970).

14. Traber, D.L., Wilson, R.D., \& Prano, L.L. Blockade of the hypertensive response to ketamine. Anesthesia \& Analgesia. Current Researches 49: 420 (1970).

15. Traber, D.L., Wilson, R.D., \& Priano, L.L. The effect of beta adrenergic blockade on the cardiopulmonary response to ketamine. Anesthesia \& Analgesia. Current Researches 49: 604 (1970).

16. Traber, D.L., Wrison, R.D., \& Priano, L.L. The effect of alpha-adrenergic blockade on the cardiopulmonary response to ketamine. Anesthesia \& Analgesia. Current Researches 50: $737(1971)$.

17. Chodoff, P. Evidena for central adrenergic action of ketamine case report. Anesthesia \& Analgesia. Current Researches 51: 247 (1972).

18. Kayama, Y. \& Iwama, K. The E.E.G. evoked potentials and single unit activity during ketamine anaesthesia in cats. Anesthesiology 36: 316 (1972).

19. Winters, W.D., Allado, T.F., Flones, C.G., \& Alcaraz, M. The cataleptic state induced by ketamine: a review of the neuropharmacology of anaesthesia. Neuropharmacology 11: 303 (1972).

20. Wong, D.H.W. \& Jenksns, L.C. An experimental study of the mechanism of action of ketamine on the central nervous system. Canadian Anaesthetists' Society Journal 21: 57 (1974).

21. Locscheke, H.H., Sweel, A., Kouch, R.H., \& Lambertsen, C.J. The effect of morphine and of meperidine upon the respiratory response of normal men to low concentrations of inspired carbon dioxide. J. Pharmacol. Exptl. Therap. 108: 376 (1953).

22. Bellville, J. \& SEED, J.C. Effect of drugs on the respiratory response to $\mathrm{CO}_{2}$. Anesthesiology 21:727 (1960).

23. ECKENHOFF, J.E. \& OCCH, S.R. The effect of narcotics and antagonists upon respiration and circulation in man. Clin. Pharmacol. and Therap. $1: 483$ (1966).

24. Keats, A.S. \& Kunosu, Y. Increased ventilation after pentobarbital in man. Fed. Proc. 16: 311 (1957).

25. American Physiological Society, H. Handbook of physiology. Circulation Vol. 1, 1st Ed. Washington, Williams and Wilkins (1962).

26. Goodman, L. \& Gilman, A. The pharmacological bases to therapeutics. 4th Ed. New York, Macmillan (1972).

27. Nuns, J. Applied respiratory physiology. Ist Ed. London. Butterworths (1969).

28. Comroe, J.H. Physiology of respiration. 1st Ed. Chicago, Year Book Medical Publishers (1970).

29. MLLAR, R.A. Plasma adrenaline and noradrenaline during diffusion respiration. J. Physiol. 150: 79 (1960).

30. Hensel, I., Braun, U., Ketrter, D., Knoll, D., Martel, J., \& Paschen, K. Studies concerning circulatory and metabolic changes during ketamine anesthesia. Anaesthetist 21: 44 (1972).

31. Lutz, H., Peter, K., \& Juhran, W. Hemodynamic responses following ketamine administration animal studies. Anaesthetist 7:8 (1972).

32. TAKKI, S., Nikki, P., JaAttella, A., \& Tammisto, T. Ketamine and plasma catecholamines. British Journal of Anaesthesia 44: 1318 (1972).

33. Tenny, S.M. Effects of carbon dioxide on the neuro humoral and endocrine mechanisms. Anesthesiology 21: 674 (1960).

34. Phuce, H.L. Effects of carbon dioxide on the cardiovascular system. Anesthesiology 21: 652 (1960). 